\title{
The Effect of Early Postpartum oral Drench Solution on Blood B-Hydroxybutyrate Concentration, Milk Yield, and Milk Composition in Holstein Cows
}

\author{
Fabio de Souza Guagnini ${ }^{1}$, Arnulfo Pineda ${ }^{2}$, Rodrigo Schallenberger Gonçalves ${ }^{1}$, Leandro DalPizzol ${ }^{3}$, David \\ Driemeier ${ }^{1}$, Félix Gonzalez ${ }^{1}$ and Felipe C Cardoso ${ }^{2 *}$
}

${ }^{1}$ School of Veterinary Medicine, Federal University of Rio Grande do Sul, Brazil

${ }^{2}$ Department of Animal Sciences, University of Illinois, USA

${ }^{3}$ School of Veterinary Medicine, University of Passo Fundo, Brazil

Submission: January 23, 2017; Published: February 06, 2017

*Corresponding author: Felipe C Cardoso, Department of Animal Sciences, University of Illinois, 1207 West Gregory Drive, 290 Animal Sciences Laboratory, Urbana, IL 61801, USA, Phone: 1 (217) 300-2303; Fax: +1 2173337088; Email: cardoso2@illinois.edu

\begin{abstract}
The aim of the present study was to evaluate the effects of oral drench solution on blood $\beta$-hydroxybutyrate (BHBA) concentration, milk yield, and milk composition of Holstein cows. Primiparous and multiparous Holstein cows $(\mathrm{n}=129)$ on commercial farms in southern Brazil were blocked by parity and calving season. Cows were randomly assigned to one of two treatments: 1) Control (40 L of water) and 2) Drench ( $40 \mathrm{~L}$ of water containing propylene glycol, rumen-protected choline, and minerals). Treatments were administered immediately after calving and 24 hours later. Cows were fed total mixed rations and milked twice daily. Body condition score (BCS) was assessed weekly. Blood BHBA concentration was measured twice weekly. Concentrations of BHBA were lower $(\mathrm{P}=0.05)$ in drench than control cows, 0.93 and $1.08 \mathrm{mmol} / \mathrm{L}$ respectively. Older (parity $\geq 3$ ) compared to younger (parity $\leq 2)$ cows had greater $(\mathrm{P}=0.02)$ blood BHBA concentration. An interaction of treatment and parity revealed that older drenched cows had lower $(\mathrm{P}=0.04)$ BHBA concentration than control $(0.93$ and $1.19 \mathrm{mmol} / \mathrm{L}$, respectively) but such differences were not observed in younger cows. Milk yield and milk composition did not differ among treatments or seasons, but differed between parity. Older compared to younger cows had greater yields of milk, fat, protein, and lactose. Drench treatment administered immediately after calving and 24 hours later decreased blood BHBA concentration in the present study, however, no affects were observed in milk yield, milk composition or BCS.
\end{abstract}

Keywords: Oral drench; Beta-hydroxybutyrate; Dairy cattle; Milk composition

Abbreviations: BCS: Body Condition Score; BHBA: Beta-Hydroxybutyrate; ECM: Energy Corrected Milk; FCM: Fat Corrected Milk; NEFA: NonEsterified Fatty Acids; PG: Propylene Glycol; RPC: Rumen-Protected Choline; SEM: Standard Error of Mean; TMR: Total Mixed Ration

\section{Introduction}

The transition period in dairy cows, comprising the period from 21 days before to 21 days after calving, is characterized by great metabolic stress associated with $30 \%$ reduction in feed intake, increased nutritional requirements, and lipomobilization Drackley et al. [1]. This period is considered of high risk to develop metabolic disorders which compromise the health of the cow Herdt [2]. Those events may induce energy, protein, and mineral deficiencies which frequently result in disorders like displacement of abomasum, metritis, mastitis, hypocalcemia, and ketosis Cameron et al. [3]. In dairy cows, abnormal concentrations of beta-hydroxybutyrate (BHBA) and non-esterified fatty acids (NEFA) have been considered sensitive indicators of severe negative energy balance. Many studies have demonstrated that high blood concentrations of those metabolites are related to the onset of several metabolic diseases LeBlanc et al. [4], Ospina et al. [5], productive inefficiency Duffield et al. [6], and reproductive failure Ospina et al. [7].

Some prophylactic treatments have been proposed in order to minimize the effects of negative energy balance and peripartal disorders such as hypocalcemia and ketosis Goff \& Horst [8], Studer et al. [9] with the aim of obtaining adequate milk yield and reproductive performance Miyoshi et al. [10]. An important prophylactic strategy to prevent puerperal disorders in dairy cows is the use of a mixture of electrolytes, glucose precursors, and calcium commonly known as drench (liquid solution administered directly into the rumen). It increases blood calcium 
concentration and minimizes energy deficiency, as well as rehydrates the animal and corrects probable hydro-electrolytic and acid-base imbalances Stokes \& Goff [11].

Numerous studies have been conducted to assess the effect of glucose precursors and mineral additives as oral drench on metabolism and health as well as productive and reproductive performance of the cow. These studies vary in the method of administration, quantity, timeframe, and more importantly in the composition of the drench. The drench solution administered to cows in the present study contained propylene glycol, minerals, and rumen-protected choline. Propylene glycol administered orally has been extensively evaluated and has shown to increase glucose, insulin, and glycogen as well as to decrease NEFA and BHBA concentrations Miyoshi et al. [10], Pickett et al. [12]. Common mineral additives supplemented to cows include calcium propionate, calcium chloride, potassium chloride, and sodium chloride. Oral administration of calcium chloride increased blood calcium levels Dhiman \& Sasidharan [13], and decreased hypocalcemia and displacement of abomasum Oetzel [14]. Potassium chloride and sodium chloride are source of essential minerals involved in the transport of glucose and amino acids into cells NRC [15]. To our knowledge there is no information of rumen-protected choline supplemented as oral drench, however, its inclusion in the diet of dairy cows has shown positive effects on lipid metabolism Cooke et al. [16] and milk production Pinotti et al. [17].

Although administration of glucose precursors and mineral additives as oral drench has shown positive results, it is labor intensive if administered for several days or weeks. Thus, the aim in the present study was to evaluate the effects of an oral drench solution administered immediately after calving and $24 \mathrm{~h}$ later on blood BHBA concentration, milk production, and milk composition of Holstein cows in southern Brazil.

\section{Material and Methods}

Animal management, diets, and experimental design Experimental procedures were approved by the Federal University of Rio Grande do Sul Animal Care and Use Committee. The study was conducted on primiparous and multiparous Holstein cows in commercial farms in Rio Grande do Sul, Brazil. At calving, cows were randomly assigned to one of two treatments in a randomized incomplete block design. Cows were blocked regarding parity $(2.85 \pm 1.71)$, body condition score (BCS; $3.18 \pm 0.51$ ), and calving season. Treatments were: 1 ) Control (40L of water) and 2) Drench (40L of water containing $500 \mathrm{~g}$ of calcium chloride, $290 \mathrm{~g}$ of propyleneglycol, $250 \mathrm{~g}$ of potassium chloride, $250 \mathrm{~g}$ of magnesium sulphate, $50 \mathrm{~g}$ of sodium chloride, and $100 \mathrm{~g}$ of rumen-protected choline (Reashure $\AA$; Balchem Corporation, NY, USA)). All cows received the respective treatment on the day of calving and 24 hours later using a siphon esophageal tube. Each drench procedure took approximately 10 minutes to be performed by a trained individual. All attempts to drench cows were successful and no associated side effects were observed. The drench treatment was a testing product formulated by the manufacturer (Nutrifarma, Rio Grande do Sul, Brazil). Drench solution was prepared and administered according to the manufacturer's instructions.

The study involved 129 cows housed in free stall and semiconfinement systems, i.e., cows were in confinement as well as allowed to pasture. Fifty-seven cows (younger (parity $\leq 2$ ) $=29$ and older (parity $\geq 3$ ) $=28$ ) received control and 72 (younger (parity $\leq 2$ )=36 and older (parity $\geq 3$ )=36) received drench treatment. During summer $(n=63)$ the enrolment period was from December 31st, 2012 to April 23rd, 2013. During winter $(n=66)$ the enrolment period was from June 11thto September 3rd, 2013. Cows were group fed diets as total mixed rations (TMR) for ad libitum intake, formulated according to NRC (2001) guidelines to meet the nutritional requirements. The TMR were offered two times daily and amounts of feed offered were adjusted daily to maintain $10 \%$ refusals. Feed and water were available at all times. The husbandry characteristics of the herd are presented in (Table 1).

Table 1: Husbandry characteristics of the herds used in experiment 1 and experiment 2.

\begin{tabular}{|c|c|c|c|}
\hline & & Herd & \\
\hline Characteristics & 1 & 2 & 3 \\
\hline Production system & Free stall & Free stall & $\begin{array}{l}\text { Semi- } \\
\text { confinement }\end{array}$ \\
\hline Milking cows & 50 & 40 & 500 \\
\hline N (experimental unit) & 31 & 17 & 81 \\
\hline Younger cows (parity $\leq 2$ ) & 15 & 7 & 41 \\
\hline Older cows (parity $\geq 3$ ) & 16 & 10 & 40 \\
\hline Milk yield (kg/day) & 36 & 40 & 30 \\
\hline Milk yield (365-day; kg) & 12,935 & 12,278 & 9,453 \\
\hline $\begin{array}{l}\text { Feed offered (kg of dry } \\
\text { matter/day) }\end{array}$ & 23.8 & 25.7 & 22.3 \\
\hline \multicolumn{4}{|l|}{$\begin{array}{c}\text { Feed composition (kg of dry } \\
\text { matter) }\end{array}$} \\
\hline Corn silage & 10.3 & 10.5 & 10.5 \\
\hline Ryegrass / Oats silage & 3 & 3.04 & 2.4 \\
\hline Ryegrass hay & 0.88 & 0.88 & - \\
\hline Piatan grass & - & - & 1.6 \\
\hline Corn & 3.92 & 4.29 & 2.96 \\
\hline Soybean meal & 4.11 & 4.94 & - \\
\hline Shell meal & - & - & 0.08 \\
\hline Wheat meal & 0.27 & 0.29 & - \\
\hline Extruded soybean & 0.88 & 0.88 & 3.98 \\
\hline Protected fat & - & 0.1 & - \\
\hline Minerals and vitamins & 0.49 & 0.53 & 0.63 \\
\hline $\begin{array}{l}\text { Sodium bicarbonate / } \\
\text { Magnesium oxide }\end{array}$ & - & 0.24 & 0.12 \\
\hline Forage: grain & $59: 41: 00$ & $56: 44: 00$ & $65: 35: 00$ \\
\hline Feed analysis & & & \\
\hline
\end{tabular}




\begin{tabular}{|c|c|c|c|}
\hline NDF (\%) & 29.5 & 28.1 & 34.5 \\
\hline Protein (\%) & 17.5 & 17.3 & 15.3 \\
\hline Net energy (Mcal/kg) & 1.58 & 1.56 & 1.6 \\
\hline
\end{tabular}

Measurements, sampling, and analyses Cows were milked two times daily and milk yields were electronically recorded. Milk composition was determined monthly through an official dairy control (Official Milk Control of Holstein Cattle Association, Passo Fundo, Rio Grande do Sul). Milk samples were analysed on the day following collection using a combination system (Delta Instruments), consisting of Somato Scope CA3A5 for somatic cell count by flow cytometry, and Lacto Scope FT1 for determination of chemical composition by mid infrared spectrometry (protein, fat, lactose and total solids). Yields of 3.5\% fat corrected milk (FCM) and energy corrected milk (ECM) were calculated using daily milk yield and milk component concentrations, as follow: $\mathrm{FCM}=(0.432 \times$ milk yield $(\mathrm{kg}))+(16.216 \times$ milk fat $(\mathrm{kg}))$ and $\mathrm{ECM}=(12.97 \times$ fat yield $(\mathrm{kg})+(7.21 \times$ protein yield $(\mathrm{kg}))+(0.327$ $\times$ milk yield (kg)) Tyrrell \& Reid [18].

Body condition score was assessed weekly by the same two trained individuals for the entire experiment using a $1=$ thin to $5=$ obese scale Ferguson et al. [19] with quarter-point increments, and the two scores were averaged for each cow. Concentrations of $\beta$-hydroxybutyrate (BHBA) in whole blood were determined on-site, twice weekly on week 1 through 4, using a hand-held meter (Precision Xtra, Abbott Diabetes Care Inc., Alameda, CA) according to the manufacturer's instructions. A blood drop was collected by puncture of coccygeal vein or artery with 20 -gauge $\times$ $2.5 \mathrm{~cm}$ needles (Becton Dickinson and Company, Franklin Lakes, NJ). Whole blood was transferred to the sensor of the test strip and values displayed on the hand-held meter were recorded onto a data collection form.

\section{Statistical analysis}

The experiment was conducted and analyzed as a randomized incomplete block design. Statistical analysis of collected data was performed using SAS (v9.4 Institute Inc., Cary, NC). Linear mixed models using the MIXED procedure Littell et al. [20] were constructed to analyse variables measured over time. Daily measurements for milk yield and BHBA were reduced to weekly means before statistical analysis. For every analysed variable (milk yield, milk components, BHBA, and BCS) the model contained the fixed effects of treatment, parity, season, time, and their interactions. Farm and cow nested within farm and season were considered random effects. Time was specified as repeated and cow nested within farm and season as subject. Initial measurements, before treatment administration, were used as covariates when analyzing BCS and blood BHBA concentration. The covariance structures considered for repeated measures analysis were compound symmetry, autoregressive order 1 , and unstructured. The autoregressive order 1covariance structure yielded the lowest Akaike information criterion and was used in the model Littell et al. [20]. Least squares means were calculated and are presented with the respective standard error (SEM). Degrees of freedom were estimated by using the KenwardRoger method Littell et al. [20] in the model statement. Residual distribution for each variable was assessed for normality and homoscedasticity. Statistical significance was declared at $\mathrm{P} \leq 0.05$ and tendency towards significance at $0.05<\mathrm{P} \leq 0.10$.

\section{Results}

Concentrations of blood BHBA measured with the handheld meter (Precision Xtra) were lower $(\mathrm{P}=0.05)$ for cows that received drench compared with control treatment (Table 2 ). Older (parity $\geq 3$ ) compared to younger (parity $\leq 2$ ) cows had greater $(\mathrm{P}=0.02)$ blood BHBA concentration, 1.06 and $0.96 \mathrm{mmol} / \mathrm{L}$ respectively. An interaction of treatment and parity $(\mathrm{P}=0.04)$ was observed for concentration of BHBA in blood (Table 2). Older cows that received drench had lower $(\mathrm{P}=0.04)$ blood BHBA concentration than those that received control (0.93 and $1.19 \mathrm{mmol} / \mathrm{L}$, respectively) but such differences were not observed in younger cows. Season had an effect $(\mathrm{P}=0.03)$ on blood BHBA concentration; although numerically small, greater concentrations were observed in summer than winter, 1.02 and $0.99 \mathrm{mmol} / \mathrm{L}$ respectively.

Table 2: Least squares means and associated standard error for body condition score (BCS), milk yield, milk composition, and blood betahydroxybutyrate (BHBA) concentration for cows that received control or drench on the day of calving and 24 hours later.

\begin{tabular}{|c|c|c|c|c|c|c|c|c|c|c|}
\hline & \multicolumn{2}{|c|}{ Treatmenta } & \multirow[b]{2}{*}{ SEM $^{\mathrm{b}}$} & \multicolumn{7}{|c|}{$\mathbf{P}^{\mathbf{c}}$} \\
\hline & Control & Drench & & Trt & Parity & $\begin{array}{l}\text { Trt } x \\
\text { Parity }\end{array}$ & Season & $\begin{array}{l}\text { Trt } x \\
\text { Season }\end{array}$ & $\begin{array}{c}\text { Trt } x \\
\text { Parity } x \\
\text { Season }\end{array}$ & Time \\
\hline BCS & 3.1 & 3.09 & 0.22 & 0.75 & 0.68 & 0.62 & $<0.01$ & 0.01 & 0.01 & $<0.01$ \\
\hline \multicolumn{11}{|c|}{ Milk yield (kg/day) } \\
\hline Milk yield & 34.6 & 35.2 & 2.95 & 0.65 & $<0.01$ & 0.46 & 0.28 & 0.09 & 0.56 & $<0.01$ \\
\hline $3.5 \% \mathrm{FCM}^{\mathrm{d}}$ & 33.8 & 34.2 & 4.42 & 0.82 & $<0.01$ & 0.03 & 0.37 & 0.23 & 0.83 & 0.04 \\
\hline $\mathrm{ECM}^{\mathrm{e}}$ & 34.1 & 34.6 & 4.03 & 0.73 & $<0.01$ & 0.04 & 0.38 & 0.24 & 0.82 & 0.04 \\
\hline \multicolumn{11}{|c|}{ Milk composition } \\
\hline Fat (\%) & 3.19 & 3.25 & 0.4 & 0.62 & 0.28 & 0.01 & 0.39 & 0.95 & 0.58 & $<0.01$ \\
\hline Fat $(\mathrm{kg})$ & 1.12 & 1.14 & 0.21 & 0.74 & $<0.01$ & 0.01 & 0.5 & 0.19 & 0.97 & $<0.01$ \\
\hline
\end{tabular}


Journal of Dairy and Veterinary Sciences

\begin{tabular}{|c|c|c|c|c|c|c|c|c|c|c|}
\hline Protein (\%) & 2.91 & 2.94 & 0.03 & 0.49 & 0.05 & 0.21 & 0.86 & 0.22 & 0.37 & $<0.01$ \\
\hline Protein (kg) & 1 & 1.04 & 0.08 & 0.44 & $<0.01$ & 0.28 & 0.44 & 0.31 & 0.79 & 0.35 \\
\hline Lactose (\%) & 4.54 & 4.52 & 0.06 & 0.68 & $<0.01$ & 0.79 & 0.34 & 0.83 & 0.09 & $<0.01$ \\
\hline Lactose (kg) & 1.58 & 1.61 & 0.13 & 0.57 & 0.02 & 0.4 & 0.42 & 0.13 & 0.77 & $<0.01$ \\
\hline Total solids (\%) & 11.6 & 11.7 & 0.4 & 0.71 & 0.1 & 0.02 & 0.88 & 0.62 & 0.14 & $<0.01$ \\
\hline $\begin{array}{c}\text { SCC (log } \\
\text { transformed) }\end{array}$ & 4.8 & 4.66 & 0.42 & 0.63 & $<0.01$ & 0.91 & 0.49 & 0.98 & 0.7 & 0.15 \\
\hline $\begin{array}{c}\text { Blood BHBA } \\
\text { (mmol/L) }\end{array}$ & 1.08 & 0.93 & 0.29 & 0.05 & 0.02 & 0.04 & 0.03 & 0.11 & 0.41 & 0.04 \\
\hline
\end{tabular}

${ }^{a}$ Treatment: control (40L of water; $\mathrm{n}=57$ ) and drench (40L of water containing $500 \mathrm{~g}$ of calcium chloride, $290 \mathrm{~g}$ of propylene glycol, $250 \mathrm{~g}$ of potassium chloride, $250 \mathrm{~g}$ of magnesium sulphate, $50 \mathrm{~g}$ of sodium chloride, and $100 \mathrm{~g}$ of rumen-protected choline; $\mathrm{n}=72$ ). All cows received the respective treatment on the day of calving and 24 hours later using a siphon esophageal tube.

${ }^{\mathrm{b}}$ Greatest standard error of mean (SEM).

${ }^{c}$ Trt=control and drench; Parity $=\leq 2$ lactations $(n=65)$ and $\geq 3$ lactations ( $\left.n=64\right)$; Trt $\times$ Parity=interaction of treatment and parity; Season=summer $(n=63)$ and winter $(n=66)$; Trt $\times$ Season=interaction of treatment and season; Trt $\times$ Parity $\times$ Season=interaction of treatment, parity, and season; Time=week or month.

${ }^{\mathrm{d}}$ Fat corrected milk.

eEnergy corrected milk.

Yields of milk, 3.5\% FCM, ECM and milk composition did not differ among treatments or seasons (Table 2). However, older (parity $\geq 3$ ) compared to younger (parity $\leq 2$ ) cows had greater yield of milk ( 37.2 and $32.6 \mathrm{~kg} / \mathrm{d}$, respectively), $3.5 \%$ FCM (37.0 and $30.9 \mathrm{~kg} / \mathrm{d}$, respectively), ECM (37.3 and $31.4 \mathrm{~kg} / \mathrm{d}$, respectively), fat yield ( 1.23 and $1.03 \mathrm{~kg} / \mathrm{d}$, respectively), protein yield $(1.09$ and $0.95 \mathrm{~kg} / \mathrm{d}$, respectively), and lactose yield $(1.67$ and $1.52 \mathrm{~kg} / \mathrm{d}$, respectively). On the other hand, concentration of protein (2.97 and $2.88 \%$ ) and lactose (4.67 and $4.39 \%$ ) were greater in younger than older cows, respectively. The interaction of treatment and parity was significant for 3.5\% FCM, ECM, fat concentration, fat yield, and total solids.

Body condition score did not differ among treatments or parity, but it differed $(\mathrm{P}<0.01)$ among seasons (Table 2). However, differences in BCS across summer and winter were numerically small (3.15 and 3.04, respectively). Two-way interaction of treatment and season $(\mathrm{P}=0.01)$, and three-way interaction of treatment, parity, and season $(\mathrm{P}=0.01)$ were observed for BCS (Table 2).

\section{Discussion}

The drench treatment administered immediately after calving and 24 hours later hours later had no effects on milk yiled and milk components. However, it decreased blood BHBA concentrations during the first 4 weeks of lactation in the present study. In addition, the interaction of treatment and parity revealed that concentrations of blood BHBA were lower in older drenched cows compared with those in control, butno treatment effect was detected in younger cows. Our results agree with Rizos et al. [21] who fed $500 \mathrm{~mL}$ of either propylene glycol (PG) or water from day 7 to the day of first ovulation and found that administration of PG compared with control resulted in decreased NEFA and BHBA, and increased glucose and insulin over the subsequent 90 minutes following dosing. Pickett et al. [12] also reported decreased non-esterified fatty acids (NEFA)

and a tendency to decreased BHBA concentrations in plasma during the first 21 days postpartum in drenched with PG cows compared with drenched with calcium soaps of palm oil fatty acids (fat).While milk yield was decreased by oral fat drench, oral PG drench had no effect on milk yield and milk composition Pickett et al. [12]. In addition, Moallem et al. [22] supplemented a dry period and lactation diet either with 500g/day of PG (through 21 days in milk), prilled fat, calcium salts of long chain fatty acids or control reporting lower prepartum plasma NEFA and lower pre and postpartum plasma BHBA concentrations in the PG and control group compared to the others.

Although results across studies are consistent regarding the effects of PG drenching in lowering concentration of NEFA and BHBA in times of extensive fat mobilization, production responses are still inconsistent. For instance, McArt et al. [23] found that PG drenched cows produced $0.69 \mathrm{~kg} /$ day greater milk yield than control. Ballard et al. [24] fed an energy supplement ( $45 \%$ beet pulp, $22 \%$ sugarcane molasses, $17 \%$ propylene glycol, and $16 \%$ calcium propionate; dry matter basis) 21 day before and after parturition reporting greater yields of milk, fat, and protein in supplemented than control cows. On the other hand, feeding a $0.11 \mathrm{~kg} /$ day of an energy supplement $(78.43 \%$ propionic acid, $21.36 \%$ calcium, $0.155 \%$ zinc and $0.053 \%$ copper; dry matter basis) 3 weeks before and after parturition decreased yield and concentration of milk fat, and had no effect on milk yield, milk protein yield and concentration Mandebvu et al. [25]. Although lower BHBA ( -1 to 7 week relative to calving) and NEFA ( -1 week to 1 day relative to calving) were reported by Hoedemaker et al. [26], no effect on milk production, animal health, or reproduction were reported by when the concentrate of the diet was enriched with $10 \%$ of $P G$ and fed to cows from -13 to 12 days relative to calving. Miyoshi et al. [10] evaluated the effects of 500mL of PG drenched daily on energy balance, plasma glucose and insulin, as well as ovarian function in early lactation ( 7 to 42 days in milk) cows. Drenched cows had increased plasma concentrations of 
glucose and insulin, decreased NEFA concentrations, and earlier days to first ovulation while no effects were observed on dry matter intake, milk yield, energy balance, days to first service, days open, and service per conception Miyoshi et al. [10].

The drench treatment administered to cows in this study contained among other ingredients propylene glycol $(300 \mathrm{~mL})$. Earlier studies Clapperton \& Czerkawski [27], Emery et al. [28] demonstrated that PG disappears from the rumen via fermentation or direct absorption. If fermented, $P G$ is metabolized to propionate in the rumen Emery et al. [28]; whereas if directly absorbed, PG is metabolized to lactate in the liver Kristensen et al. [29]. Both lactate and propionate can be converted to glucose via gluconeogenesis in the liver. In turn, glucose supply stimulates insulin secretion from the pancreas, which down regulate fatty acid mobilization from adipose tissue and thus, ketone bodies production Nielsen \& Ingvartsen [30]. Rumen-protected choline (RPC; $100 \mathrm{~g}$ ) was also a component of the drench treatment. Choline is important compound for the synthesis phosphatidylcholine and acetylcholine Pinotti et al. [17]. While acetylcholine is an important neurotransmitter Pinotti et al. [17], phosphatidylcholine is essential to maintain cell membrane structure Davidson et al. [17], hepatic synthesis and secretion of very low density lipoprotein from the liver Cooke et al. [31], and biosynthesis and secretion of milk Kinsella [32]. Several studies have evaluated RPC reporting positive effects on milk yield Pinotti et al. [17], milk composition, and fat mobilization Cooke et al. [5], Zom et al. [33]. Decreased NEFA in RPC fed cows suggests increased capacity of the liver to uptake, oxidize, or esterify NEFA Pineda \& Cardoso [34] and hence, reduce ketogenic substrate. Calcium chloride (500g), potassium chloride (250), magnesium sulphate (250g), and sodium chloride (50g) were also components of the drench treatment. Oral supply of large amount of calcium salts to force calcium into the blood by passive diffusion can be used to increase calcium concentration during the peripartum period Stokes \& Goff [11]. Oral administration of calcium chloride increased blood calcium levels Dhiman \& Sasidharan [35] and decreased hypocalcemia and displacement of abomasum Oetzel [14]. Potassium chloride and sodium chloride are source of essential minerals involved in the transport of glucose and amino acids into cells, whereas magnesium sulphate plays an important role in maintaining calcium homeostasis around calving NRC [15]. Moreover, it has been shown that oral administration of potassium chloride decreased nonesterified fatty acid concentration in cows with experimentally induced hypokalemia Constable et al. [36]. To us, it is clear that lower blood BHBA concentration in drenched cows may be the results of propylene glycol being metabolized to glucose, which in turn may decrease fat mobilization either by the availability of glucose or by insulin secretion down regulating NEFA mobilization from adipose tissue and thus, reducing ketone bodies (mostly BHBA) production. Another possibility may be that choline from RPC increased the capacity of drenched cows to pack and export triglycerides in very low density lipoproteins, decreasing circulating NEFA and so ketone bodies production.
Milk yield and milk composition were not affected by treatments, however, these variables were affected by parity with older cows (parity $\geq 3$ ) having greater yields of milk, fat, protein, and lactose, which has been well already stablished [37].

\section{Conclusion}

The administration of a drench solution containing propyleneglycol, minerals, and rumen-protected choline immediately after calving and 24 hours later decreased blood BHBA concentration in the present study. Effect of drench treatment on blood BHBA concentration was more pronounced in older than younger cows, however, no affects were observed in milk yield, milk composition or BCS.

\section{Acknowledgements}

The authors gratefully acknowledge UFRGS, SPV/UFRGS, Nutrifarma, UniãoQuimica/AgenerUnião, and Zoetis for supporting this project. In addition, our gratitude is extended to Fernando Stedile, Adair Becker, and Dieter Roese for lending the animals to carry out this study.

\section{References}

1. Drackley JK, Overton TR, Douglas GN (2001) Adaptations of glucose and long-chain fatty acid metabolism in liver of dairy cows during the periparturient period. Journal of Dairy Science 84: E100-E112.

2. Herdt TH (2000) Ruminant adaptation to negative energy balance. Influences on the etiology of ketosis and fatty liver. Vet Clin North Am Food Anim Pract 16(2): 215-230.

3. Cameron REB, Dyk PB, Herdt TH, Kaneene JB, Miller R, et al. (1998) Dry cow diet, management, and energy balance as risk factors for displaced abomasum in high producing dairy herds. J Dairy Sci 81(1): 132-139.

4. LeBlanc SJ, Leslie KE, Duffield TF (2005) Metabolic predictors of displaced abomasum in dairy cattle, J Dairy Sci 88(1): 159-170.

5. Ospina PA, Nydam DV, Stokol T, Overton TR (2010) Evaluation of nonesterified fatty acids and $\beta$-hydroxybutyrate in transition dairy cattle in the northeastern United States: Critical thresholds for prediction of clinical diseases. J Dairy Sci 93(2): 546-554.

6. Duffield TF, Lissemore KD, McBride BW, Leslie KE (2009) Impact of hyperketonemia in early lactation dairy cows on health and production. J Dairy Sci 92(2): 571-580.

7. Ospina PA, Nydam DV, Stokol T, Overton TR (2010) Associations of elevated nonesterified fatty acids and $\beta$-hydroxybutyrate concentrations with early lactation reproductive performance and milk production in transition dairy cattle in the northeastern United States. J Dairy Sci 93(4): 1596-1603.

8. Goff JP, Horst RL (1994) Calcium salts for treating hypocalcemia: carrier effects, acid-base balance, and oral versus rectal administration. J Dairy Sci 77(5): 1451-1456.

9. Studer VA, Grummer RR, Bertics SJ, Reynolds CK (1993) Effect of prepartum propylene glycol administration on periparturient fatty liver in dairy cows. J Dairy Sci 76(10): 2931-2939.

10. Miyoshi S, Pate JL, Palmquist DL (2001) Effects of propylene glycol drenching on energy balance, plasma glucose, plasma insulin, ovarian function and conception in dairy cows. Anim Reprod Sci 68(1-2): 2943.

11. Stokes SR, Goff JP (2001) Case study: evaluation of calcium propionate and propylene glycol administered into the esophagus of dairy cattle at calving. The Professional Animal Scientist 17: 115-122. 
12. Pickett MM, Piepenbrink MS, Overton TR (2003) Effects of propylene glycol or fat drench on plasma metabolites, liver composition, and production of dairy cows during the periparturient period. J Dairy Sci 86(6): 2113-2121.

13. Dhiman TR, Sasidharan V (1999) Effectiveness of calcium chloride in increasing blood calcium concentrations of periparturient dairy cows. J Anim Sci 77(6): 1597-1605.

14. Oetzel GR (1996) Effect of calcium chloride gel treatment in dairy cows on incidence of periparturient diseases. J Am Vet Med Assoc 209(5): 958-961.

15. NRC (National Research Council) (2001) Nutrient Requirements of Dairy Cattle. National Academy Press, Washington, USA.

16. Cooke RF, Del Río NS, Caraviello DZ, Bertics SJ, Ramos MH, et al. (2007) Supplemental choline for prevention and alleviation of fatty liver in dairy cattle. J Dairy Sci 90(5): 2413-2418.

17. Pinotti L, Baldi A, Dell'Orto V (2002) Comparative mammalian choline metabolism with emphasis on the high-yielding dairy cow. Nutrition Research Reviews 15(2): 315-332.

18. Tyrrell HF, Reid JT (1965) Prediction of the energy value of cow's milk. J Dairy Sci 48(9): 1215-1223.

19. Ferguson JD, Galligan DT, Thomsen N (1994) Principal descriptors of body condition score in Holstein cows. J Dairy Sci 77(9): 2695-2703.

20. Littell RC, Henry PR, Ammerman CB (1998) Statistical analysis of repeated measures data using SAS procedures. J Anim Sci 76(4): 12161231.

21. Rizos D, Kenny DA, Griffin W, Quinn KM, Duffy P, et al. (2008) The effect of feeding propylene glycol to dairy cows during the early postpartum period on follicular dynamics and on metabolic parameters related to fertility. Theriogenology 69(6): 688-699.

22. Moallem U, Katz M, Arieli A, Lehrer H (2007) Effects of peripartum propylene glycol or fats differing in fatty acid profiles on feed intake, production, and plasma metabolites in dairy cows. J Dairy Sci 90(8): 3846-3856.

23. McArt JAA, Nydam DV, Ospina PA, Oetzel GR (2011) A field trial on the effect of propylene glycol on milk yield and resolution of ketosis in fresh cows diagnosed with subclinical ketosis. J Dairy Sci 94(12) 6011-6020.

24. Ballard CS, Mandebvu P, Sniffen CJ, Emanuele SM, Carter MP (2001) Effect of feeding an energy supplement to dairy cows pre- and postpartum on intake, milk yield, and incidence of ketosis. Animal Feed Science and Technology 93(1-2): 55-69.

25. Mandebvu P, Ballard CS, Sniffen CJ, Tsang DS, Valdez F, et al. (2003) Effect of feeding an energy supplement prepartum and postpartum on milk yield and composition, and incidence of ketosis in dairy cows. Animal Feed Science and Technology 105(1-4): 81-93.

26. Hoedemaker M, Prange D, Zerbe H, Frank J, Daxenberger A, et al. (2004) Peripartal propylene glycol supplementation and metabolism, animal health, fertility, and production in dairy cows. J Dairy Sci 87(7): 2136-2145.

27. Clapperton JL, Czerkawski JW (1972) Metabolism of propane-1: 2-diol infused into the rumen of sheep. Br J Nutr 27(3): 553-560.

28. Emery RS, Burg N, Brown LD, Blank GN (1964) Detection, occurrence, and prophylactic treatment of borderline ketosis with propylene glycol feeding. J Dairy Sci 47(10): 1074-1079.

29. Kristensen NB, Danfaer A, Røjen BA, Raun BML, Weisbjerg MR, et al. (2002) Metabolism of propionate and 1,2-propanediol absorbed from the washed reticulorumen of lactating cows. J Anim Sci 80(8): 21682175 .

30. Nielsen NI, Ingvartsen KL (2004) Propylene glycol for dairy cows: A review of the metabolism of propylene glycol and its effects on physiological parameters, feed intake, milk production and risk of ketosis. Animal Feed Science and Technology 115(3-4): 191-213.

31. Davidson S, Hopkins BA, Odle J, Brownie C, Fellner V, et al. (2008) Supplementing Limited Methionine Diets with Rumen-Protected Methionine, Betaine, and Choline in Early Lactation Holstein Cows. J Dairy Sci 91(4): 1552-1559.

32. Kinsella JE (1969) Biosynthesis of Choline-Containing Lipids by Ruminant Mammary Tissue. Journal of Dairy Science 52(11): 18751877.

33. Zom RLG, van Baal J, Goselink RMA, Bakker JA, de Veth MJ, et al. (2011) Effect of rumen-protected choline on performance, blood metabolites, and hepatic triacylglycerols of periparturient dairy cattle. Journal of Dairy Science 94(8): 4016-4027.

34. Pineda A, Cardoso FC (2015) Effects of rumen-protected choline with calcium salts of long chain fatty acids on milk yield and milk composition of middle and late lactation Holstein cows. Livestock Science 175: 47-58.

35. Constable PD, Hiew MWH, Tinkler S, Townsend J (2013) Efficacy of oral potassium chloride administration in treating lactating dairy cows with experimentally induced hypokalemia, hypochloremia, and alkalemia. J Dairy Sci 97(3): 1413-1426.

36. Pinotti L, Baldi A, Politis I, Rebucci R, Sangalli L, Dell Orto V (2003) Rumen-protected choline administration to transition cows: effects on milk production and vitamin E status. Journal of Veterinary Medicine. A Physiology Pathology Clinical Medicine 50(1): 18-21.

37. Emery RS, Brown RE, Black AL (1967) Metabolism of DL-1,2 propanediol-2-14C in a lactating cow. J Nutr 92(3): 348-356.

This work is licensed under Creative

Commons Attribution 4.0 Licens

DOI:10.19080/JDVS.2017.01.555554
Your next submission with Juniper Publishers will reach you the below assets

- Quality Editorial service

- Swift Peer Review

- Reprints availability

- E-prints Service

- Manuscript Podcast for convenient understanding

- Global attainment for your research

- Manuscript accessibility in different formats

( Pdf, E-pub, Full Text, Audio)

- Unceasing customer service

Track the below URL for one-step submission https://juniperpublishers.com/online-submission.php 